\title{
Higher Education Institution in the 21st Century - Key Factors for Prospective Students
}

\section{Enikő KORCSMÁROS, Szilvia T. KOSÁR and Bence CSINGER*}

J. Selye University, Komarno, Slovakia, korcsmarose@ujs.sk; kosars@ujs.sk; csinger.bence@gmail.com

* Corresponding author: csinger.bence@gmail.com

\begin{abstract}
In our study, we examine the most important key factors that play an important role in the lives of students about to enter higher education. Higher education institutions contribute career preparation by providing a wide range of internship opportunities for students. In addition, it contributes greatly to personal development. The aim of our research is to provide a comprehensive picture of the most significant influencing factors for students in 21st century Hungary that determine the choice of a higher education institution. In the course of our study, we conducted a quantitative survey among secondary schools in Hungary, which was implemented in the form of a direct mail questionnaire survey. Our results prove that the most important factor for students nowadays is to get a suitable job opportunity after their studies. In the case of students with a good and excellent academic average, the professionalism of their future teachers and the quality of instruction are decisive for their further education.
\end{abstract}

Keywords: higher education; key factors; further learning

JEL Classification: I20; I21; I23

\section{Introduction}

The 21st century brought drastic social and economic changes. This period is the century of the knowledge-based society, where human knowledge, which becomes an almost direct productive force, is of unprecedented importance in the life of mankind. As a result, the knowledge economy has emerged, putting the economic structures of the 21st century on a new footing. The most important institutions of the knowledge society deal with the production, distribution and reproduction of knowledge. This role is now played by educational institutions, including higher education. Today, the most important thing is to develop relationships, communication and cooperation, and through its potential, to approach a given problem from different perspectives. In addition, it is important to mention a kind of technological and social paradigm shift, as nowadays ideas, concepts, and solutions are the main parameters. (Hudson, 2006)

Modern education systems form a complex structure consisting of several interconnected levels. The ensemble of these forms the school system itself, which is divided into subsystems with more or less institutional characteristics. (Halász, 2001)

Each country has its own individual higher education system, but each is part of the European Higher Education Area (EHEA). The system is the result of a unique international collaboration in higher education and the political will of 49 countries with different political, 
cultural and academic traditions, which has created a step-by-step area of shared commitment over the past twenty years. The 49 countries fully agree and accept the reform of higher education based on common key values such as free expression, autonomy of institutions, independent student unions, academic freedom, and free movement of students and faculty. In order to sustain this process, the countries, institutions and stakeholders in the European region are constantly transforming their higher education systems. The aim is to make them compatible, thus strengthening their quality assurance mechanisms. The main goal of these countries is to increase the mobility of teachers and students and to facilitate employability. (Ehea, 2021)

Hungary has an advanced higher education system consisting of 38 universities and 29 colleges. With regard to universities, it can be said that there are 27 public, 9 private and ecclesiastical institutions in the country (Derényi, 2018).

An article in Eduline in 2019 shows that the Hungarian government has waived the compulsory secondary language exam for higher education. However, the advanced level of graduation, also required as an admission requirement, remains. Tamás Schanda, Parliamentary Secretary of State at the Ministry of Innovation and Technology, said last year that students who enroll in a higher education institution in 2020 and already have a language exam will have a significant advantage in admission, as this knowledge is extra points. He added that students who passed the language exam before applying would not be short of it either, as it would still be needed to obtain a degree, and would be a huge advantage during higher education, as it would make it easier for them to learn about the latest research findings. (Eduline, 2019)

In the 2019/2020 academic year, 64 higher education institutions conducted training in Hungary. The number of applicants for full-time bachelor's and master's degrees increased by 3.7 thousand in 2019. With regard to bachelor education, it can be said that, based on the current year's calculation, the number of applicants increased by $6.2 \%$ in 2019, and it can be said that the proportion of students admitted was $70 \%$ of first-place applicants. In the 2019/2020 academic year, 204 thousand students continued their studies in the full-time courses of Hungarian higher education institutions, which also meant an increase of $1.7 \%$ based on the current year's calculation. (Hunagrian Central Statistical Office, 2019)

Figure 1 clearly shows that over the years, the number of people in tertiary education is unfortunately declining. Based on the data, we examined the development of the population between 1992 and 2001, as this age group was facing the choice of a higher education institution between 2010 and 2019. The gray part of the chart shows the number of students in higher professional training, the purple part in bachelor's education, the orange part in master's education and the blue part in doctoral education.

Student decisions can be divided into two groups: individual and group decisions. The choice of institution as well as further education is typically considered a group decision among high school students, as it is a major decision that will determine the future, within which the family has an extremely important role to play. In later stages of life, this decision is already passed on to the individual, but at the same time the role of group influence remains. (Rámháp, 2017) 


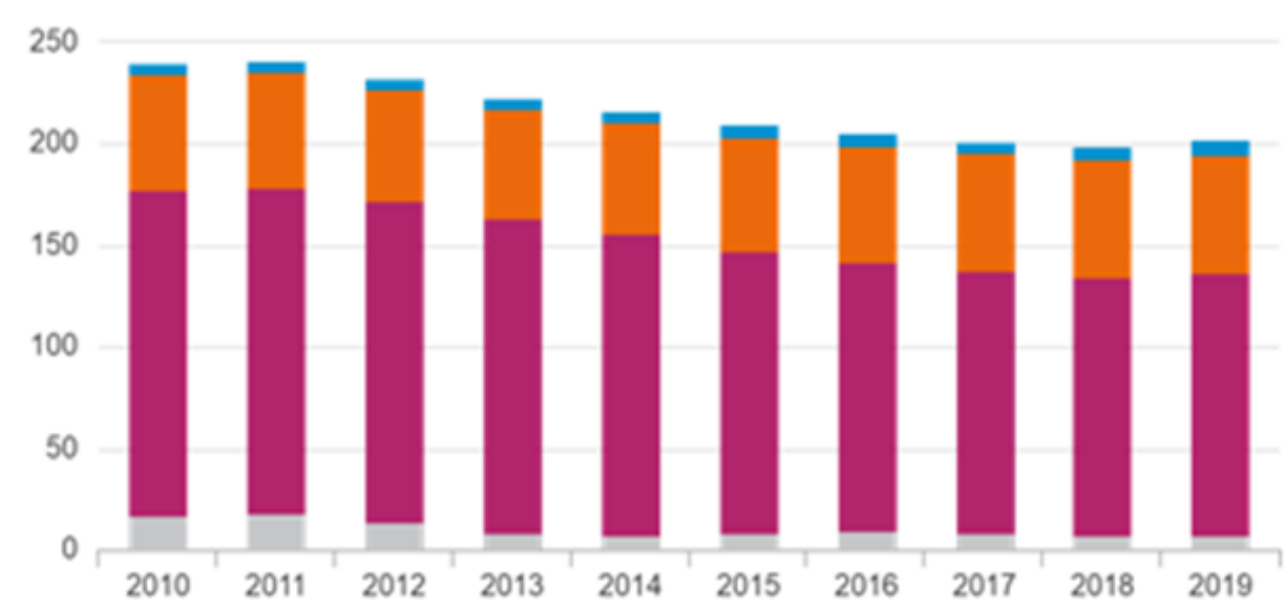

Figure 1. Changes in the number of students studying full-time in higher education institutions between 2010-2019. Source: Hungarian Central Statistical Office (2019)

We distinguish five different decision roles, which are: initiator, influencer, decision maker, purchaser, and user. With regard to higher education, the initiator is the student or parent who wishes to continue his or her studies, who wants his or her child to continue his or her studies, and at a later stage in life, the workplace where higher education is expected. The influencing category in this case is extremely wide-ranging. Parents, family, friends, acquaintances, society and the workplace also influence the decision. In terms of consumer behavior, we distinguish between individual (motivation, values, lifestyle, personality) and environmental (culture, reference groups, family) influencing factors. When choosing a higher education institution, the individual, the family or even the workplace can play a decision-making role. The opinion of the prospective student is dominant in the selection of the major as well as the admission strategy, but the parent is competent in financial matters. Parents leave room for individual goals, professional interest and attitudes, but since they finance the studies or, in other cases, the additional costs, they have the final say. The decision is often influenced by the opinions of peers, and financial issues are influenced by the family situation. We can also talk about mutual decisions, which are typically present in the case of settlement choice and housing issues. Parents can also provide students with good advice and experience in assessing the value of a degree as well as future employment opportunities. (Rámháp, 2017; Császár - Németh, 2011)

In the education system, therefore, we can talk about decisions made more or less freely, which are formed by weighing the expected benefits and expenses. Every decision has the consequence that market-like processes are present in the education system and competition also appears. Individual decisions that can be seen as consumer decisions related to education can be described as the relationship between the demand for forms of education and different institutional options as supply and demand. (Halász, 2001)

Table 1 provides a comprehensive overview of the changes in key factors that play a key role among students in selecting a higher education institution. In order to expand this literature review, we decided to examine these motivational factors in relation to Hungary.

Higher education institutions need to have a well-developed marketing strategy that provides ongoing information to their own target group. 
Table 1. The most important factors in choosing a higher education institution

\begin{tabular}{|l|l|l|}
\hline \multicolumn{1}{|c|}{ Hooley \& Lynch, 1981 } & \multicolumn{1}{|c|}{ Lin, 1997 } & \multicolumn{1}{c|}{ Soutar \& Turner, 2002 } \\
\hline $\begin{array}{l}\text { Suitability of the course, place of } \\
\text { university, academic reputation, } \\
\text { type of university (old or modern), } \\
\text { family opinion, job opportunities, } \\
\text { quality of teaching, university } \\
\text { atmosphere. }\end{array}$ & $\begin{array}{l}\text { Quality of education, career } \\
\text { opportunities, reputation, } \\
\text { curriculum, level of study, faculty } \\
\text { qualifications. }\end{array}$ & $\begin{array}{l}\text { Suitability of the course, reputation, } \\
\text { job opportunities, quality of teaching. }\end{array}$ \\
\hline
\end{tabular}

Higher education institutions need to have a well-developed marketing strategy that provides ongoing information to their own target group.

The decisions that students make when choosing a higher education institution are often related to the obvious and hidden costs of college or university visits, in a word, the resources needed for attendance (attendance collage). Researchers find that high school graduates who want to enroll in four-year institutions and their family members consider a number of variables before making their final decision. Students usually consider whether a particular institution offers some form of financial incentive support. Institutional characteristics are also taken into account. Several researchers have examined how the geographical location of students influences their application to a higher education institution. They concluded that students living in zones where college and university opportunities are available are more likely to apply to these institutions. Based on these, it was stated that the local accessibility of higher education institutions contributes significantly to the increase in the education of local students. (Canché, 2018)

\section{Methodology}

After reviewing the theoretical part of our analysis, the next important part of our research was the presentation of the results of our study.

We considered it an important factor to present our results to the reader in an appropriate way after answering the central question. As a result, we illustrate the results of the research using various graphic solutions. Based on the order of importance of the motivational factors encountered in graduating high school students, the first step was to create a preference order. In addition, we aimed to make a step-by-step representation of the elements of the pyramid we created on which higher education institutions have an influential power. A total of 311 high school students joined our primary data collection. When filling in the questionnaires, we placed great emphasis on the recipients, is the leaders and teachers of secondary schools and grammar schools, asking for the help of students who want to study further, and strengthening the camp of students with excellent or good grades. Taking these factors into account, 270 of the 311 responses received were evaluable for us.

With the help of the hypothesis formulated in connection with the topic, we wanted to research what motivational factors are present among Hungarian secondary school students when choosing a higher education institution. Prior to the statistical analysis of the data, our hypothesis was as follows: 
H1: There is a linear relationship between the reputation of higher education institutions and other factors considered important by the authors.

In our hypothesis analysis, we examined variables that were measured on a five-point Likert scale. Based on the concepts defined by the Sajtos-Mitev (2007) pair of authors, the variables measured on the Likert scale are metric. As a result, in our case, we will test the formulated hypothesis with correlation analysis.

To examine the closeness of the data, the Pearson correlation coefficient (r), has been chosen, which can be determined:

$$
r=\frac{\sum_{i=1}^{N}\left(x_{i}-\bar{x}\right)\left(y_{i}-\bar{y}\right)}{\sqrt{\sum_{i=1}^{N}\left(x_{i}-\bar{x}\right)^{2} \sum_{i=1}^{N}\left(y_{i}-\bar{y}\right)}}
$$

where $\bar{x}$ is the mean of $x_{-} i$ and $\bar{y}$ is the mean of $y \_i$. The value of the correlation coefficient can range from -1 to +1 , where the absolute value of the pointer indicates the closeness of the relationships and its sign indicates the intensity of the relationship.

\section{Results}

Based on our research results, we created a preference order, which is shown in Figure 2. During the preparation of our order of preference, we divided each motivational factor into three categories, which were marked with three different colors in the figure. The section marked in the bottom gray contains the influencing factors that have the least impact on students in making decision. Above this are the factors that already greater influence, but they are not the most important. At the top of the pyramid, we placed the variables that can be defined as the most influential factors based on our research.

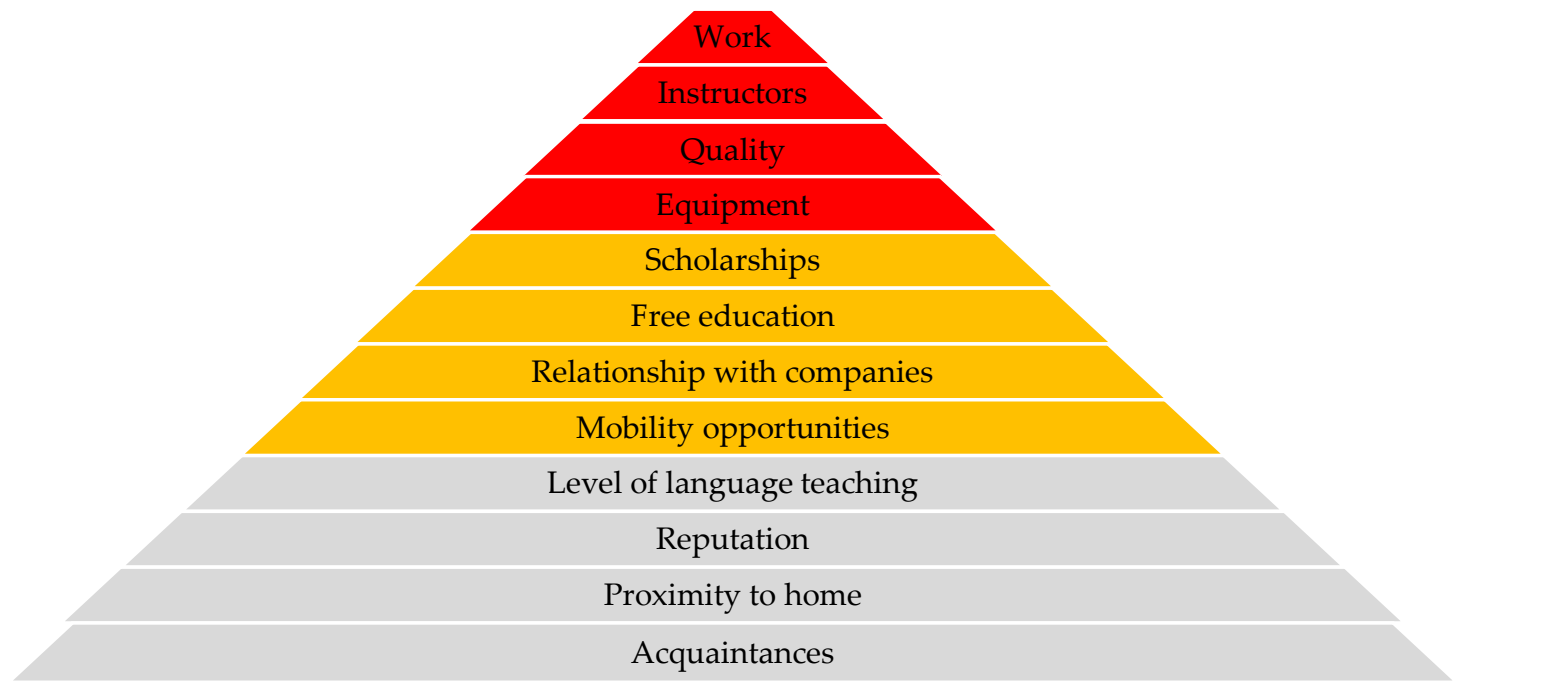

Figure 2. Order of preference for the most important factors when selecting a Hungarian higher education institution

The least important variable for students is that their acquaintances also visit (2.36) the higher education institution. Furthermore, the proximity of the university to their home is not relevant (2.79). The next level of preference order is the reputation of the university (3.60), which is more than 0.8 points ahead of the other two levels. However, reputation cannot be separated from several higher levels, as good equipment, quality, and the professionalism of 
the lecturers will sooner or later entail an increase in the reputation of a university. The level of language teaching (3.81), mobility opportunities (3.84) and contact with companies (3.89) are not negligible aspects either. At the next two levels, there are material-related factors: free education (4.02) and scholarship opportunities (4.05), which have already been rated above four. Suppose a particular student is admitted to a cost-effective course and is not eligible for scholarships because of his or her position. This can have a significant impact on your choice of a foreign but free higher education institution. At the highest levels of the pyramid are the elements that are a basic expectation in a reputable higher education institution. The fourth most important factor is the equipment of the university (4.20), here we can think of the technical equipment, the classrooms, but even the library. Above this is the quality of the university (4.28), which is most often found in the rankings of the various higher education institutions. Students involved in the research identified two factors as the most important, as the difference between them is only one-tenth.

Since all variables were measured on a Likert scale for the statement under study, a correlation analysis was performed to study their relationship, the results of which are illustrated in Table 2.

Table 2. Examination of the H1 hypothesis by correlation analysis

\begin{tabular}{|c|c|c|c|}
\hline & Pearson Correlation & Sig. & N. \\
\hline University standard & 0.397 & 0 & 270 \\
\hline Professionalism of trainers & 0.006 & 0.919 & 270 \\
\hline University equipment & 0.127 & 0.037 & 270 \\
\hline Level of language teaching & 0.082 & 0.181 & 270 \\
\hline Mobility opportunities & 0.163 & 0.007 & 270 \\
\hline Proximity to home & 0.066 & 0.281 & 270 \\
\hline Influence of acquaintances & 0.190 & 0.002 & 270 \\
\hline Free education & 0.033 & 0.590 & 270 \\
\hline Scholarship opportunities & 0.042 & 0.496 & 270 \\
\hline University-company relations & 0.098 & 0.110 & 270 \\
\hline Future well-paying job opportunities & 0.063 & 0.304 & 270 \\
\hline
\end{tabular}

Observing the Pearson correlation coefficient, we can only identify one variable that correlates with the reputation of the university. This variable is the standard. Based on these, it can be stated that the more important the reputation of the higher education institution is for the students involved in the research, the more important it is that the quality of the institution is good. The relationship can also be said to be positive and moderately strong. In addition to the formulated hypothesis, the authors also outlined two assumptions in the second chapter.

\section{Discussion}

In the first part of our study, we provided an insight into the 21st century higher education system. As a next step we outlined the methodology of the study and finally review the results of the research. Our questionnaire was created using Survio and Google Form Building software. After conducting our quantitative questionnaire survey, we formulated 
our hypotheses on the topic. After that we sent our survey many secondary schools in Hungary with the aim of examining the motivation of graduate students for further education and to get an answer to the question of which factors influence them the most when deciding on the choice of institution. The feedback results were coded using Microsoft Excel, and then the validity of our hypotheses was examined using the SPSS program. In the course of our analysis, we obtained the result that nowadays the future job opportunities, the professionalism of the instructors, the quality of the education, and the equipment of the institution are the most important factors that are taken into account when they choose a higher education institution. In our hypothesis analysis, we formulated the assumption that there is a linear relationship between the reputation of the institution and other factors that we consider important. We obtained the result that only one variable correlates with the reputation of the university, and that is the standard of the university.

\section{Conclusions}

Taking into account Table 1 based on the literature review and our own results, it can be said that the factors which influencing graduate students in Hungary have not changed much in the last 40 years. Based on our results, the primary task of a higher education institution is to provide the right teaching background, to pay great attention to the quality of education, and to consider the equipment of the institution. In our opinion, if these factors are given a strong emphasis by higher education institutions, it will contribute to the good placement of graduates in the labor market. As a limitation of our research, it is definitely important to mention the ongoing health crisis situation, which has forced high schools to switch to online education, which greatly reduced the willingness to fill. There are so many opportunities for research. Our goal is to expand the scope of research for the future, as well as to conduct an international comparative analysis. In addition, we would like to repeat our research in the future, which provides an opportunity to examine how the influencing factors are changing over the years, which are essential to further learning.

Acknowledgments: The scientific article is a partial output from the KEGA project 005UJS-4/2019 entitled "Streamlining Managerial Sills of the generations $Z$ and $Y$ by gamification on the context of linking science and practice", which is solved at the Faculty of Economics and Informatics of the J. Selye University in Komárno.

\section{References}

Canché, G. S. M. (2018). Nearby collage enrollment and geographical skills mismatch: (Re)conceptualizing student out-migration in the American Higher Education System. The Journal of Higher Education, 89(6), 892-934. https://doi.org/10.1080/00221546.2018.1442637

Császár, M. Z., \& Németh, J. (2011). Some aspects of human capital production in hungarian higher education. Central European Regional Policy and Human Geography, 1(1), 27-35.

https://www.researchgate.net/profile/Zsuzsa_M_Csaszar/publication/266874625_SOME_ASPECTS_OF_H UMAN_CAPITAL_PRODUCTION_IN_HUNGARIAN_HIGHER_EDUCATION/links/56c1a05708aee5cacc f7cc3b.pdf

Derényi, A. (2018). A felsőoktatás rendszere Magyarországon. Tempus Közalapítvány. https://tka.hu/nemzetkozi/9518/a-felsooktatas-rendszere-magyarorszagon

Eduline. (2019). Milliók nézik ezt a videót: így kampányolnak a Harvard hallgatói. https://eduline.hu/campus_life/20191122_kulonleges_video_egyetemistak

Ehea. (2021). Info. Europen Higher Education Area and Bologna Process. http://www.ehea.info/ 
Halász, G. (2001). Az oktatási rendszer. Müszaki Könyvkiadó.

Hooley, G. J., \& Lynch, J. E. (1981). Modeling the student university choice process through the use of conjoint measurement techniques. European Research 9(4) 158-170.

Hudson, C. (2006). Regional development partnerships in Sweden: a way for higher education institutions to develop their role in the processes. Higher Education: The International Journal of Higher Education and Educational Planning, 51(3), 387-410. https://doi.org/10.1007/s10734-004-6416-3

Hungarian Central Statistical Office. (2019). Oktatási adatok, 2019/2020 (Educational data 2019/2020). https://www.ksh.hu/docs/hun/xftp/idoszaki/oktat/oktatas1920/index.html

Lin, L. (1997). What are student education and educational related needs? Marketing and Research Today, 25(3), 199-212.

Rámháp, S. (2017). Felsőoktatási továbbtanulási motivációk Magyarországon. A változó ifjúság és a piacosodó felsőoktatás tükrében. Doktori értekezés tervezet. (Motivations for further education in higher education in Hungary. In the light of changing youth and marketable higher education. Doctoral dissertation draft.) Széchenyi István Egyetem. Regionális- és Gazdaságtudományi Doktori Iskola.

https://rgdi.sze.hu/images/RGDI/honlapelemei/fokozatszerzesi_anyagok/Ramhap_Szabolcs_doktori_dissz ertacio.pdf

Sajtos, L., \& Mitev, A. (2007). SPSS Kutatási és adatelemzési kézikönyv. Budapest: Alinea Kiadó.

Soutar, G. N., \& Turner, J. P. (2002). Students' preferences for university: A conjoint analysis. The International Journal of Educational Management, 16(1), 40-45. https://doi.org/10.1108/09513540210415523 